\title{
An Anniversary Postponed and a Diagnosis Delayed: Vietnam and PTSD
}

More than 40 years after it ended, we can't forget Vietnam and we are still arguing about why it went wrong, who was to blame and whether it was all worth it.

Ken Burns ${ }^{1}$

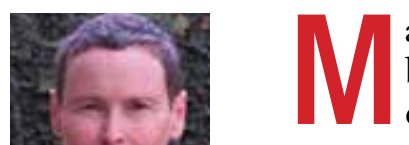

M any events both personal and public have been deferred during the 15 plus months of the pandemic. Almost everyone has an example of a friend or family member who would have been sitting at what President Biden, during his memorial speech for the 500,000 victims of the virus referred to as the "empty chair" at a holiday gathering sans COVID-19. ${ }^{2}$ For many in our country, part of the agonizing effort to awaken from the long nightmare of the pandemic is to resume the rhythm of rituals national, local, and personal that mark the year with meaning and offer rest and rejuvenation from the daily toil of duty. There are family dinners now cautiously resumed due to vaccinations; small celebrations of belated birthdays in family pods; socially distanced outdoor gatherings suspended in the cold communicable winter now gingerly possible with the warmth of spring.

As a nation, one of the events that was put on hold was the commemoration of the Vietnam War. On March 16, 2021, following guidance from the Centers for Disease Control and Prevention, the US Department of Veterans Affairs (VA) announced it was postponing commemoration events "until further notice." ${ }^{3}$ Annually, the VA partners with the US Department of Defense, state, and local organizations to recognize "the service and sacrifices made by the nearly 3 million service members who served in Vietnam."

In 2012, President Barak Obama signed a proclamation establishing a 13-year commemoration of the 50th anniversary of the Vietnam War. ${ }^{5}$ Five years later, President Donald Trump signed the War Veterans Recognition Act of 2017, designating March 29 annually as National Vietnam War Veterans Day. ${ }^{6}$ Though many of the events planned for March and April could not take place, the Vietnam War Commemoration (https:// www.vietnamwar50th.com) offers information and ideas for honoring and supporting Vietnam War veterans. As Memorial Day approaches in this year of so much loss and heroism, I encourage you to find a way to thank Vietnam veterans who may have received the opposite of gratitude when they initially returned home.

As my small contribution to the commemoration, this editorial will focus on the psychiatric disorder of memory: posttraumatic stress disorder (PTSD) and how the Vietnam War brought definition—albeit delayed - to the agonizing diagnosis that too many veterans experience.

The known clinical entity of PTSD is ancient. Narrative descriptions of the disorder are written in the Mesopotamian Epic of Gilgamesh and in Deuteronomy 20:1-9. ${ }^{7}$ American and European military physicians have given various names to the destructive effects of combat on body and mind from "soldier's heart" in the American Civil War, to "shell shock" in World War I to "battle fatigue" during World War II. ${ }^{8}$ These were all descriptive diagnoses field practitioners used to grasp the psychosomatic decompensation they observed in service members who had been exposed to the horrors of war. The VA was the impetus and agent of the earliest attempts at scientific definition. The American Psychiatric Association further developed this nosology in 1952 with the diagnosis of gross stress reaction in the first Diagnostic and Statistical Manual of Mental Disorders (DSM)-1. ${ }^{9}$

The combat experience shaped the definition: the stressor had to be extreme, the civilian comparison would be a natural disaster; the reaction could occur only in a previously normal individual, it would be attributed to the extant psychiatric condition in anyone with a premorbid illness; and if it did not remit by 6 months, another primary psychiatric diagnosis must be assigned.

From our vantage point, this set of criteria is obviously woefully inadequate, yet it was at least a beginning of formal recognition of the experience that veterans endured in wartime and real progress compared with what happened next. 
When DSM-1 was revised in 1968, the diagnosis of gross stress reaction was eliminated without explanation. Researcher Andreasen and others speculate that its disappearance can be attributed to association of the diagnosis with war in a country that had been at peace since the end of the Korean War in $1953 .{ }^{10}$ Yet military historians among my readers will immediately counter that the Vietnam War began 2 years later and that the year of the revision saw major combat operations.

Many veterans living with the psychological and physical suffering of their service in Vietnam and the organizations that supported them advocated for the psychiatric profession to formally acknowledge post-Vietnam syndrome. ${ }^{11}$ Five years after the end of the Vietnam War, the experts who authored DSM-III, decided to include a new stress-induced diagnosis. ${ }^{12}$ Although the manual did not limit the traumatic experience to combat in Vietnam as some veterans wanted, there is no doubt that the criteria reflect the extensive research validating the illness narratives of thousands of service men and women.

The DSM-III criteria clearly had war in mind when it stipulated that the stressor had to be outside the range of usual human experience that would likely trigger significant symptoms in almost anyone as well as specifying chronic symptoms lasting more than 6 months. Despite the controversy about the diagnosis, Vietnam veterans helped bring the PTSD diagnosis to official psychiatric nomenclature and in a more recognizable form that began to capture the intensity of their reexperiencing of the trauma, the psychosocial difficulties numbing caused, and the pervasive interference of hyperarousal and vigilance many aspects and areas of life. ${ }^{13}$

The National Vietnam Veterans Longitudinal Study examined the course of PTSD over 25 years, using the newly formulated diagnostic criteria for PTSD. ${ }^{14}$ Results were reported to Congress in 2012 and showed that $11 \%$ of men and $7 \%$ of women who were in a war theater were still struggling with PTSD 40 years after the war. Of those, 37\% met major depressive disorder criteria. Male veterans who in 1987 still met criteria for PTSD were twice as likely to have died than the comparator group of veterans without PTSD. Two-thirds of veterans with PTSD from war zone exposure discussed behavioral health or sub- stance misuse concerns with a health care provider, and $37 \%$ of those were receiving VA care. ${ }^{14}$

Given these disturbing data, perhaps the best way we can pay homage to the aging Vietnam veterans is to support continued research into effective evidence-based treatments for PTSD and funding for the training and recruiting of mental health practitioners to all 3 branches of federal health care who can deliver that care compassionately and competently.

\section{Disclaimer}

The opinions expressed herein are those of the author and do not necessarily reflect those of Federal Practitioner, Frontline Medical Communications Inc., the US Government, or any of its agencies.

\section{References}

1. The Vietnam War: a new film by Ken Burns and Lynn Novick, to air fall 2017 on PBS. Press release. Updated August 17, 2020. Accessed April 26, 2021. https://www.pbs.org/about/about-pbs /blogs/news/the-vietnam-war-a-new-film-by-ken-burns-and -lynn-novick-to-air-fall-2017-on-pbs

2. The White House Briefing Room. Remarks by President Biden on the more than 500,000 Americans lives lost to COVID-19. Published February 22, 2021. Accessed April 26, 2021.https://www.whitehouse.gov/briefing-room/speeches -remarks/2021/02/22/remarks-by-president-biden-on-the-more -than-500000-american-lives-lost-to-covid-19/

3. US Department of Veterans Affairs. Vantage Point. VA postpones 50th anniversary of the Vietnam War commemoration events. Published March 16, 2021. Accessed April 26, 2021. https:// blogs.va.gov/VAntage/72694/va-postpones-50th-anniversary -vietnam-war-commemoration-events

4. US Department of Defense. Nation observes Vietnam War Veterans Day. Published March 29, 2021. Accessed April 26, 2021. https://www.defense.gov/Explore/Features/Story /Article/2545524/nation-observes-vietnam-war-veterans-day

5. The White House. Commemoration of the 50th anniversary of the Vietnam War. Published May 25, 2012. Accessed April 26, 2021. https://obamawhitehouse.archives.gov/the-press -office/2012/05/25/presidential-proclamation-commemora tion-50th-anniversary-vietnam-war

6. Vietnam War Veterans Recognition Act. Public Law 115-15. U.S. Government Publishing Office, Washington DC, 2017.

7. Crocq M-A, Crocq L. From shell shock and war neurosis to posttraumatic stress disorder: a history of psychotraumatology. Dialogues Clin Neurosci.2000;2(1):47-55. doi:10.31887/DCNS.2000.2.1/macrocq

8. US Department of Veterans Affairs. History of PTSD in veterans: Civil War to DSM-5. Accessed April 26, 2021. https://www.ptsd .va.gov/understand/what/history_ptsd.asp

9. American Psychiatric Association. Diagnostic and Statistical Manual of Mental Disorders. Washington, DC: American Psychiatric Association; 1952.

10. Andreasen NC. Posttraumatic stress disorder: a history and a critique. Ann NY Acad Sci. 2010;1208;67-71. doi:10.1111/j.1749-6632.2010.05699.x

11. Shata CF. Post-Vietnam syndrome. The New York Times. Published May 6, 1972. Accessed April 26, 2021. https://www .nytimes.com/1972/05/06/archives/postvietnam-syndrome.html

12. American Psychiatric Association. Diagnostic and Statistical Manual of Mental Disorders. (DSM-III). Washington, DC. American Psychiatric Association; 1980.

13. Kinzie JD, Goetz RR. A century of controversy surrounding posttraumatic stress stress: spectrum syndromes: the impact on DSM-III and DSM-IV. J Trauma Stress. 1996;9(2):156-179. doi:10.1007/BF02110653

14. Schlenger WE, Corry NH. Four decades later: Vietnam veterans and PTSD. Published January/February 2015. Accessed April 25, 2021. http://vvaveteran.org/35-1/35-1_longitudinalstudy.html 